\title{
Police Violence Against Black Protesters: A Public Health Issue
}

\author{
James F. Anderson ${ }^{1}$, Tazinski P. Lee ${ }^{2}$, Adam H. Langsam ${ }^{3}, \&$ Kelley Reinsmith-Jones ${ }^{4}$ \\ ${ }^{1}$ College of Arts \& Sciences, Professor of Criminal Justice, East Carolina University, Greenville, NC, USA. \\ ${ }^{2}$ College of Professional Studies, Professor of Criminal Justice, Grambling State University, Grambling, LA, USA. \\ ${ }^{3}$ College of Liberal Arts, Professor of Sociology, Northeastern State University, Tahlequah, OK, USA. \\ ${ }^{4}$ School of Health and Human Performance, Associate Professor of Social Work, East Carolina University, Greenville, \\ NC, USA. \\ Correspondence: James F. Anderson, Professor, Department of Criminal Justice, East Carolina University, Greenville, \\ NC, USA.
}

Received: December 10, 2021

Accepted: January 14, 2022

Available online: January 21, 2022

doi:10.11114/ijsss.v10i2.5456

URL: https://doi.org/10.11114/ijsss.v10i2.5456

\begin{abstract}
With the increased number of documented cases of violence perpetrated by police against protesters of the Black Lives Matter movement, public health officials are starting to list police violence as a health risk or a public health issue for black Americans. Using several timely theoretical explanations, we explore reasons why law enforcement officers routinely inflict violence against black protesters and avoid criminal stigma. Although police use of excessive force and untimely killings of blacks have always been criminal justice issues, the number of negative health consequences that are emerging after violent police confrontations implicates public health concerns. We argue that several strategies can be used to reduce police violence in the future.
\end{abstract}

Keywords: public health, symbolic interaction, critical race theory, implicit bias, training in policing protests, civil rights violations

\section{Introduction}

In the wake of protests led by the Black Lives Matter movement over systemic racism and the violent deaths of blacks being killed by police, researchers, as well as local and national news media outlets report that instead of tensions abetting between blacks and law enforcement, matters are growing increasingly worse as the number of violent confrontations between protesters, police, and journalists continue to rise (Thomas, Gabbatt, \& Barr, 2020). Blacks contend that when they stage demonstrations to express frustration, they are merely exercising their constitutional right to peacefully assemble to protest racism and the deaths of community members killed by police. They argue these matters are exacerbated by cases that reveal the deceased was unarmed and posed no threat to police officers or others on the scene. Police officers contend that during protests, tempers flare and escalate when protests get out of control and crowds become agitated and someone throws an object into their direction or when they give the crowd a command to disburse only to find protesters challenging their authority and power. When this occurs, police respond to protesters and the media with excessive force, tear gas, pepper spray grenades, kinetic impact projectiles, and other militarized forms of policing (Barker, Baker, \& Watkins, 2021; Amnesty International, 2020).

In the aftermath of violence, protesters contend that they did nothing to provoke violence and police are often unable to demonstrate that protesters forced them to act in an aggressive manner. Amnesty International (2020) reports that police officers routinely violate the human rights of protesters, medics, reporters, and legal observers who gather to protest the unlawful killings of black people and to call for reforms to systemic racism in the US. It also reports the irony of the same racism and brutality that protesters are speaking out against is directed at them by police when they use excessive force and militarized tactics to squash demonstrations (Amnesty International, 2020). Whether one believes protesters or the police version of what actually-transpires during protests, it is undeniable that tensions and a lack of trust exists between the two groups. Unfortunately, when there are protests in reaction to deaths, there are often victims with serious bodily injuries after protests. Chandler (2021) reports that police violence directed at protesters is a public health issue that leaves victims suffering from hearing loss, concussions, traumatic brain issues, burns, contusions, breathing difficulties and other respiratory issues. This implicates both the criminal justice as well as the public health systems. As such, this 
manuscript is divided into three parts. Part One presents theoretical explanations about police violence against blacks. Part Two discusses police violence and the public health implication. Part Three addresses policy recommendations. In the end, we argue that violent encounters between black protesters and police officers can be reduced.

\section{Theoretical Explanations of Police Violence Against Blacks}

When examining the violence perpetrated against blacks by police officers, there are several dynamics that must be addressed. First, the level of precision and normalcy that police demonstrate when committing acts of brutality against blacks while discharging their duties is concerning since they act with unrestrained impunity. Police have subjected blacks to physical beatings and murder as they operate undeterred by the prospect that a fellow officer will intervene to help the victim because it is the legal, moral, and human action to take if not simply to remind the officer that this conduct is illegal. Second, blacks demand for justice needs to be contextualized, examined, and understood. Because police violence against black protesters is critically important and timely, we believe theoretical explanations such as Critical Race Theory; Power Threat Theory; and Symbolic Interactionism offer the framework necessary to understand these dynamics.

\subsection{Critical Race Theory}

Critical Race Theory (CRT) examines the complicity that American jurisprudence plays in upholding white supremacy, especially in areas such as race, class, gender, and sexual orientation (Crenshaw et al., 1995). Critical race theorists believe that historically white supremacy has been institutionalized in the economic, political, and legal structures of American society to the extent its cultural and structural embeddedness are unrecognizable to many in the country's majority. CRT scholars contend that the law and other apparatuses of the justice system are used as mechanisms to maintain class dominance and racial division (Lynch \& Groves, 1989). Therefore, they argue that the law is not colorblind and race in America can never be neutral since racial power is exercised legally and ideologically and serves as the biggest supporter of racial constructs that sustain themselves as concrete realities. In fact, as Taylor (1998) explains, "CRT challenges the experiences of whites as the normative standard and grounds its conceptual framework in the distinctive experiences of people of color (p. 122)." The theory contends that to understand racial oppression, one must consider it from the racial dynamics of those who have lived racial inequalities and experienced exclusion. CRT questions whether a racist social structure can deliver equitably on upholding "the rule of law" or "dispense equal protection" to everyone fairly. The theory challenges how the law socially constructs and maintains social dominance and subordinates minority groups. CRT embraces the use of perspectives given by oppressed people who experience racial oppression, injustices, and inequalities in society. CRT scholars accept oppressed people's perceptions of justice, truth, fairness, and experiences and refer to them as the true knowers (Taylor, 1998).

\subsection{Power Threat Theory}

Power Threat Theory (PTT) argues that when the majority population believes that minorities have evolved into a threat to their powerbase, especially in areas such as social, political, and economic resources, it imposes punitive sanctions to thwart those efforts (Bodapati, Anderson, \& Branson, 2008). The theory holds that when black and Latino populations increase to the point where whites must compete instead of relying on white privilege, they will use punitive sanctions and other forms of social control (e.g., voter suppression, gerrymandering, redistricting and others) to shift the balance of power back into their favor. Recently, these actions have become evident since demographers forecast that by 2042, whites will no longer be the majority in the United States. Consequently, this has manifested in an increase in hate crimes; hate group membership; as well as protests from domestic terrorists such as the KKK, Proud Boys, and other extremists (Wilkerson, 2020). PTT postulates that in areas where blacks and others outnumber whites, they immediately pose a threat to the white powerbase. For example, many whites view protests and demonstrations by the Black Lives Matter Movement, as threatening to the status quo. As such, law enforcement officers are allowed to use militarized policing such as SWAT and violence to dismantle and subdue protesters. For example, officers routinely, and often with impunity, use excessive and deadly force on minorities who exercise their constitutional right to stage a lawful demonstration. The majority often justifies this disparate treatment out of fear they will lose power and privilege. Scholars suggest that because whites perceive large gatherings of minority protestors as threatening to their powerbase, they turn a blind eye to police violence including unprovoked deaths. However, when an angry mob of whites committed insurrection on January $6^{\text {th }}$ by seizing control of the nations' Capitol, attacked police chanting "Stop the Steal" and overwhelmed police by killing one and injuring several officers, and caused politicians to be removed by secret service officers for safety reasons, this degree of threat, did not give rise to law enforcement officers responding with excessive or deadly force confirming Thomas and colleagues (2020) finding that police often treat members of the far-right and white supremacists with leniency. According to PTT, when the majority feels its powerbase is threatened by minorities, it will use punitive measures to instill fear and keep them under control. It may even support and elect racist politicians and turn a blind eye to its own members engaging in insurrectionist activities if the goal is to preserve 
the existing social arrangement (Wilkinson, 2020).

\subsection{Symbolic Interactionism}

Symbolic interactionism postulates that the interactions people have with others shape the conceptions they form of themselves and influence their behavior. Therefore, people will live up or down to what others expect of them (Barkan, 2006). Others will influence our behavior via a process of verbal and symbolic communication such as gestures, signs, words, or images that represent meaning to all who communicate and receive them. Through interacting with others, people interpret meaning that they incorporate into their self-image for better or worse (Blumer, 1969; Siegel, 2006). The process is compelling and influences how people see reality from the point of view of those they share an interest or relationship with such as a political group, social class, clique, police, family, or race (e.g., identity politics). In either group, communications and symbols are used to indicate whether one displays the values held out as important by the group. Scholars argue that within the context of group dynamics, sometimes there is no objective reality, but rather, subjective interpretation can inform behavior (Blumer, 1969).

Policing is instructive in this regard. The police culture provides officers with symbolic labels and teaches them about what is expected when they interact with each other. They are also taught that there are only two groups: those who break laws and others who enforce laws. Critics argue that such a belief system promotes the "blue wall of silence" that police are socialized into after joining the force. This is seen when police officers accused of using excessive force are protected by fellow officers who witnessed their illegal behavior. They are complicit in the cover-up (Gaines \& Kappeler, 2008). The expectation of supporting a fellow officer includes not breaking one's silence when an officer is guilty of wrongdoing. This is revealed during Black Lives Matter demonstrations when police use excessive and deadly force on peaceful protesters. As this occurs, other officers on the scene refuse to intervene to protect the lives of citizens from police use of unjustifiable force. Even when these violent encounters are captured on video by demonstrators or on lookers, officers who do not respond with violence against protesters are unwilling to assist prosecutors in bringing a criminal case against fellow officers. Moreover, police label the people they are sworn to serve and protect. They are taught to view some of them as threating to their powerbase and authority, especially those who have historically been constructed as "problems," "enemies of the state," or groups that agitate and challenge the social order. Recently, groups have challenged the legality of police practices by demanding social justice, accountability, and equality under the law have been added to the list of enemies. They are black men and women, LGBTIQ groups, and whites who question the legitimacy of police authority. When police confront these groups, they respond with militarized tactics as they mete out violence resulting in injury and sometimes death.

\section{Police Violence and the Public Health Implication}

The Centers for Disease Control (CDC), as well as the World Health Organization (WHO) have declared assaultive violence a public health issue because of the health consequences associated with experiencing violence (Dahlberg \& Mercy, 2009). In the aftermath of violence, victims often need medical and psychological help to treat their victimization. The CDC and WHO report after experiencing violence, some victims are treated for trauma and stress, physical injuries, and mental health issues (Alang et al., 2017). Sometimes, the experience has an indirect impact on their family members requiring that they also seek physical and mental health treatment (Fix et al., 2021). Recently, researchers have reported that police have inflicted violence on black protesters that has resulted in death, physical injuries, acute racial stress, and other injuries. They also argue that the constant threat of police violence poses a serious health risk to the black community because of the acute stress associated with being a potential victim of violence and the level of force (e.g., excessive/deadly) shown on television of fatal black shootings (Copper \& Fullilove, 2016; Edwards, Lee, \& Esposito, 2019).

While achieving health equality is the mission of public health, many experts including epidemiologists have been reluctant to list police violence, especially its use of force among the health risks and threats to the black community (APHA, 2018). In fact, some scholars have reported that public health investigators have produced little research criticizing the police for engaging in behavior that poses a threat to the public (Copper et al., 2005). More specifically, the public health system has been accused of taking even longer to address the nature and prevalence of police violence perpetrated against black women (Fedina et al., 2018). Similarly, Krieger and colleagues (2015) revealed that while public health researchers focus on health problems such as physical, sexual, and psychological violence, they neglect to give police violence the critical attention it deserves. Therefore, placing it on the margins of public health. Outraged by the neglect in the public health literature, WHO reports that in the U.S., police brutality is rooted in racism and impacts both black males and females, yet black and indigenous women are significantly more likely to be killed by police compared with other women.

Blacks are also more likely to suffer psychological trauma associated with police brutality since most are keenly aware that violence is possible whenever they interact with police. For black Americans, this is an unescapable reality (Murphy, 
2020). Critical race theorists contend that whiteness provides protection against police brutality (Kahn et al., 2016). However, protecting blacks from police violence may be more difficult than criminal justice experts, legal scholars, and health officials are willing to concede since the practice is grounded in white supremacy perpetuated by structural racism with its laws, court systems, police, policies, and other institutions created to limit opportunities and life chances of minorities (Gee \& Ford, 2011; Crenshaw et al., 1995). Moreover, critical race theorists argue that what whites view as a routine encounter with police typically means something different and possibly life threatening to blacks since any encounter with police can escalate to fatal violence, or other health problems such as high blood pressure; diabetes; self-rated health; asthma; and poor health linked to harassment, higher rates of stop-frisks, and other police practices that are not found in white neighborhoods (Copper et al., 2005).

Researchers contend that public health experts silence on police violence and the risk it poses to the health of blacks is well documented (Cooper \& Fullilove, 2016). They argue that police brutality goes beyond any physical force meted out on blacks, but rather, it morphs into emotional, psychological, and physical manifestations ranging from premature deaths, bodily injuries, sexual assaults, and stress produced by a legacy of distrust and terror, as well as repeated acts of victimization and intimidation (Bandes, 1999). These same scholars contend that because police brutality also dehumanizes and degrades its victims, it creates negative health outcomes. The fact that the public health system has not declared police violence an epidemic is concerning since it is a social determinant that causes severe health problems to large segments of minority populations that face the daily threat of excessive force, as well as experiencing other manifestations of poor health linked to police violence.

Because black women have reported that in some of their encounters with police, they experienced tear gas, anxiety, beatings, sexual assaults, and exposure to infectious diseases, the American Public Health Association (2016) posits that these types of police behaviors constitute a public health problem because acts of sexual assault and physical injuries invariably lead to the spread of infectious diseases and the need to treat bodily injuries by professionals trained in medicine and other areas of health care. Health experts argue some consequences of police violence and aggression displayed at protesters could include death; physical injuries; and negative psychological reactions such as racist-incident-based trauma; anger; anxiety; depression; PTSD; mental breakdowns; suicide attempts; and the withdrawal from social relationships (Bryant-Davis et al., 2017; Krug et al., 2002).

\section{Policy Recommendations}

Criminal justice and public health experts argue that to prevent police violence, efforts should be made to address the root causes of the problem, as well as hold police criminally and civilly responsible for engaging in brutality (Barna, 2020; Gaines \& Kappeler, 2008; Signorelli, 2006). To that end, we provide policy recommendations that are potentially effective at reducing police violence against black protesters. We recommend reforming grand juries; diversity training in implicit bias; training in policing protests; community health and violence-reduction strategies, and legal remedies to prevent the use of excessive and deadly force.

\subsection{Reforming Grand Juries}

In wake of the estimated 4, 400 people shot (mostly minorities) and killed by police since 2015, there has been public outcry demanding justice since these deaths are often followed by grand juries failing to issue indictments holding police criminally responsible for what appears to be unjustifiable deaths (Fox et al., 2019). Simmons (2017) reports that grand juries fail to indict police for a number of reasons that range from prosecutorial discretion that manifests in a conflict of interests faced by prosecutors who work with police officers facing charges to prosecutors acting non-aggressively when holding police responsible by presenting grand juries with less than compelling evidence of police wrong doing, to not monitoring grand juries to determine whether the deceased was presented in a racially biased manner. Legal experts also criticize the private nature of grand jury proceedings, especially when no indictments are returned after suspicious police killings of unarmed minorities (Fox et al., 2019). Scholars contend that this has led to a national movement aimed at reforming the grand jury system. Some suggest that they be subjected to a fourfold approach when police are involved in fatal shootings: use of tasks forces; improve access; remove secrecy, or use an independent prosecutor (Simmons, 2017). First, when a grand jury in Minnesota failed to indict a police officer after he shot and killed a 17-year-old black teenager, Hennepin County created a task force to investigate the grand jury procedure. It discovered that people of color were disproportionately represented as suspects before the grand jury and underrepresented as members of the grand jury. Second, several states have introduced methods to increase access to grand juries. Private citizens have been empowered to petition to convene a grand jury when any citizen collects the statutory minimum number of signatures, a judge is legally obligated to summon a grand jury to investigate an alleged crime. Third, experts suggest removing the secrecy of grand juries by allowing public access to the indictment phase of the investigation. This can occur by expanding disclosure requirements in cases involving police shootings which mandates that prosecutors release a report explaining its decision not to issue an indictment. Grand juries could also be 
given an opportunity to release their reports to the public explaining why they failed to indict. Fourth, use an independent prosecutor when a grand jury is tasked with investigating cases of police use of excessive or deadly force.

\subsection{Diversity Training in Implicit Bias}

Although the relationship between police and the minority community has historically been volatile, recent interactions among both groups have come under scrutiny, owing to police use of excessive force resulting in deaths (Gaines \& Kappeler, 2008; Teplin, 2000). Studies reveal that police often stop minorities based solely on race, especially when profiling drug couriers and traffickers (Gaines, 2006). A Bureau of Justice Statistics study found that while blacks, Hispanic, and white drivers were equally likely to be pull over by police, blacks and Hispanics were more likely to be searched, arrested, and threatened with force compared to white drivers (Department of Justice, 2007). This revelation prompted some experts to accuse police officers, as well as entire departments of being racist towards minorities since their actions have resulted in racial profiling (Glaser, 2015; Department of Justice, 2007; Skolnick \& Caplovitz, 2001). Studies also show that racial profiling is so entrenched in American policing that minorities are generally viewed by officers as "symbolic enemies" solely because they have African or Arabic sounding names, different styles of dress, hairstyles, or other attributes that run counter to what police perceive as traditional. Eberhardt et al. (2004) reported that police officers were even more likely to report that black faces look criminal. This implicit bias can influence police when they encounter people they consider as nonconforming or "others" such as young black male protesters. Oddly, police officers may not consider themselves racists, yet they possess implicit biases about others. This fact makes it very likely that they will engage in discriminatory practices and violent behavior against minorities (Spencer et al., 2016).

Research conducted on implicit biases and how they impact police behavior reveal that such biases are based on the cumulative perceptions that people construct about others that often have a profound effect on outcomes (Greenwald et al., 2015 Glaser \& Knowles, 2008). Some scholars argue that implicit biases are based on stereotypes (i.e., blacks are more prone to violence and crime) that have become deeply embedded in the American culture. Studies show that stereotype research on race tends to influence the perception of threat. Police view blacks as more threatening and dangerous. Therefore, they are more likely to use force without much deliberation (Goff et al., 2008). Implicit biases exist outside one's conscious awareness and control since they are always present. Researchers report that implicit biases are commonly found in policing since the nature of law enforcement brings police in contact with people they identify as suspects, criminals, and undesirables. This suggests that whether police officers are racists is influenced by the implicit biases they acquire from the policing culture and society. Consequently, they make decisions without attributing them to concrete occurrences (Devine, 1989). As such, police view blacks as more aggressive compared to whites which impacts their decision to use excessive or deadly force as was revealed by the January $6^{\text {th }}$ incident.

To address implicit bias in policing, experts recommend that policymakers diversify law enforcement agencies and offer intervention training programs such as intergroup contact; counter-stereotypic exemplars; stereotype negation training; and multifaceted interventions. First, a meta-analysis of intergroup contact with non-negative contact with out-group members found a great reduction in bias. The study revealed it was an effective way to reduce racial bias when four elements are present: equal status between the groups in the situation; common goals; intergroup cooperation; and the support of authorities (Pettigrew \& Tropp, 2006). Furthermore, it revealed that the number of contact meetings with the four criteria present, led to a reduction in bias. Second, exposure to outgroup members who controvert group-based stereotypes can also reduce bias (Park \& Glaser, 2011). Moreover, counter-stereotypic stimuli also revealed a reduction in implicit bias compared with those participants who received other interventions. Third, training police to not use stereotypes by saying "no" to stereotypical sayings was found to reduce activation of stereotypes in future behavior. Last, a combination of strategies such as stereotype replacement, counter-stereotype imaging, individuation, and increasing opportunities for intergroup contact were found to successfully reduce implicit bias (Devine et al., 2012). Although most departments train officers in cultural competency, implicit bias training can help reduce the effect of cultural biases and stereotypes that often influence police decision making when encountering minorities.

\subsection{Training in Policing Protests}

National reports from watchdog groups and outside investigators reveal that in several major cities, police response to protests escalated volatile situations into violence and excessive use of force because officers lacked professional training to handle large protests. Several states reported that police who are deployed to manage crowds lack the necessary training to respond with appropriate behavior since few officers have received appropriate training in specialized units. Because of this, police are trained to treat protests as though they are riots. The reports stated that instead of police focusing on de-escalation strategies, they emphasize disorder control which escalates already tense situations and lead to violence (Barker et al., 2021). Nationally, police are overresponding to protests as if they are riots as revealed by the riot gear (i.e., riot helmets and batons) they wear when confronting civil protests. Therefore, what is needed to reduce police violence is training on how to manage large crowds of protesters and working relationships 
with community leaders who can put them in contact with members and protest organizers. Some experts argue that the most effective efforts may include inviting community activists to join in police protests training. The rationale is that activists can help sensitize police departments to the concerns and needs of protesters as well as foster better police community relations.

Others suggests that police leaders should develop better ways to supervise crowd control, and only use militarized responses as the last resort since research finds that paramilitary weapons and riot gear leads to the same violence police are trying to suppress (Barker et al., 2021). Experts also suggest that police officers involved in managing crowds of protesters need training in de-escalation strategies to defuse potentially explosive situations when they confront oppositional groups (Barker et al., 2021). Police protests training must teach officers to recognize the different types of public demonstrations and when to respond with appropriate behavior. Ideally, these police training programs should use proven verbal de-escalation strategies that can deflect volatile situations. These programs should also discuss the role of supervisors and administrators before and during protest. Above all, these programs should teach police appropriate interventions and response strategies in public protests (Barker et al., 2021).

\subsection{Community Health and Violence-Reduction Strategies}

Public health experts argue health departments can play a critical role in reducing police violence by partnering with the community to build mutual trust. Collaboratively, they can create solutions and interventions that address police violence. Health departments must understand American policing and the root causes of police violence towards the minority population. Together with the community, health departments can address police violence by conducting public health research that accurately frames racism, power imbalances, and structural inequities that influence police violence. Experts contend that health departments must also have a clear understanding of social determinants of health. After building relationships with communities, health departments can use their authority, voice, and position to present the realities about how police use of force negatively affects the health of black community residents. Health departments are in the unique position to inquire and advocate for better data and reporting procedures on police violence. To that end, health departments can advocate for policies, practices, and budgets that could prioritize reducing the role of police and using their budgets to invest in social determinants of health (Barna, 2020).

The American Public Health Association (APHA) presented a viable public health strategy to address police violence. APHA recommend diverting funds from some areas of law enforcement by shifting monies into community-based programs designed to invest in social detriments of health such as employment initiatives and affordable housing. In addition, the strategy is designed to alleviate stressors that are placed on police officers (that could partly explain their use of force) such as having to serve the community as untrained social workers, counselors, and mental health professionals. APHA's strategy enlists the help of trained social workers, counselors, and mental health professionals by expanding the shareholders who will be responsible for keeping the community safe. Experts believe that this will be the best course of action given that police officers are currently asked to fill these roles and are stretched to the limit with their day-to-day operations. Since they are untrained to perform many responsibilities given them, the manifestation of their violence has been meted out on protesters and others that they have contact. Some experts attribute police excessive use of force to stress and the lack of training and patience to perform competently in these areas (Barna, 2020).

\subsection{Using Legal Remedies to Prevent the Use of Excessive and Deadly Force}

Citizens typically file lawsuits under Title 42 of the United States Code, Section 1983 civil action against police departments over alleged violations of their rights (Gaines \& Kappeler, 2008; Signorelli, 2006). It allows victims whose constitutional rights have been violated by government officials to sue in federal court to recover monetary damages. For example, a protester, injured by an officers' use of excessive force (while exercising the first amendment right to protest) could bring a lawsuit against police alleging a constitutional right violation by the officer. In the lawsuit, a lawyer must convince a judge or jury that a police officer in his capacity as a law enforcement officer violated the plaintiffs' constitutional rights (Signorelli, 2006). In excessive force cases, when law enforcement officers misuse their authority on the local or state level, they have acted under color of law and can be held liable in a civil rights lawsuit. Any case that involves an officer's use of excessive or deadly force constitutes a violation of the Fourth Amendment when performed in a manner that violates the reasonableness standard created by the Court. In cases where citizens are beaten, shot, or killed and it is later determined that they were unarmed and did not pose a threat of death during a protest, these matters are likely to be ruled as a civil rights violation.

Section 1983 claims can also include municipal liability. In City of Canton v. Harris (1989, p.1205), the Court ruled that inadequate police training may serve as the basis of liability under Section 1983 if that failure amounts to "deliberate indifference" to the rights of persons with whom the police come into contact and those deficiencies in their training program are closely related to the victims' injuries. The Court stated that "it may happen that in light of the duties 
assigned to specific officers or employees, the need for more or different training is so obvious, and the inadequacy so likely to result in violations of constitutional rights, and the policymakers of the city can reasonably be said to have been deliberately indifferent to the need." This suggests that municipalities are persons and can also be liable for violations of Section 1983 (See also Monell v. Department of Social Services) where the Court overruled Monroe v. Pape and viewed governmental entities (e.g., police department) as persons and held that they can also be sued under Section 1983 claims.

Given that watchdog groups and independent investigations find that police routinely use excessive force after widespread protests and demonstrations occur after the killing deaths of black men, and that most police officers and agencies are not properly trained to recognize and respond to protests with de-escalation strategies, the refusal to adequately train and accept that there are differences between protests and riots could signal to a judge or jury that police are unwilling to change as they continue acting in a manner that is deliberately indifferent to the plight of the people they are sworn to serve and protect. Thus, inviting more Section 1983 lawsuits when victims allege civil rights violations.

Consequently, these lawsuits name the officer, his immediate supervisor; the police chief; the agency; and members of the city council as parties. Moreover, plaintiffs claim that the officer is liable for shooting or choking the deceased; the immediate supervisor or police chief is liable for failure to properly train, direct, or supervise the officer; and the agency is liable for allowing past customs, practices, and policies to continue that contributed to the behavior that resulted in injury or death (del Carmen \& Walker, 2004).

In wrongful death lawsuits, surviving family members, or relatives of the deceased can file a tort action alleging the death of a family member was caused by unjustified police action. To prevail in a wrongful death claim, the plaintiff must demonstrate that the death of a family member was unjustified given what a reasonable person would have done given similar circumstances (del Carmen, 1991). In such cases, the plaintiff initiates these suits when a police officer engages in the excessive use of force such as beating a protester to death, stands on the neck of a protester until he dies; shoots and kills a protester; uses a chokehold resulting in death; an officer's random gunfire kills an innocent citizen, or any type of police recklessness during a protest that results in someone's death.

\section{Conclusion}

Police use of excessive force against black protesters is a national problem that is likely to continue unless policies are implemented to address needed reforms in law enforcement practices and training. Unfortunately, as revealed in this work, many police officers have implicit biases that influence how they discharge their duties, especially when they confront minorities. The police culture also socializes officers into having an "us" versus "them" mentality that impacts their worldview which encourages the use of force along with concealing theirs and other officer's criminal behavior. These issues are at the core of what must be addressed at the time candidates enter their respective police academy. Moreover, the lack of training in managing protests, almost invariably encourages officers to abuse their authority since they currently rely on militarized policing and SWAT techniques including the use of tear gas when confronting peaceful demonstrators. The situation is critical since police use of excessive force against protesters can quickly escalate into criminal law violations, civil rights violations, as well as ignite health issues that officials at CDC and WHO report could have short and long term negative consequences on the victims.

\section{References}

Alang, S., McAlpine, D., McCreedy, E., \& Hardeman, R. (2017). Police Brutality and Black Health: Setting the Agenda for Public Health Scholars. AJPH Perspectives, 107(5), 662-669. https://doi.org/10.2105/AJPH.2017.303691

American Public Health Association. (2016). American Public Health Association Law Enforcement Violence as a Public Health Issue. American Public Health Association. Policy No. LB-16-02.

Amnesty International. (2020). USA: Law Enforcement Violated Black Lives Matter Protester'Human Rights, Documents Acts of Police Violence and Excessive Force. Retrieved from

https://www.amnesty.org/en/latest/press-release/2020/08/usa-law-enforcement-violated-black-lives-matter-proteste rs-human-rights/

Bandes, S. (1999). Patterns of Injustice: Police Brutality in the Courts. Buffalo Law Review, 47(3), 1275-1342. https://doi.org/10.2139/ssrn.165395

Barkan, S. E. (2006). Criminology: A sociological understanding (3rd ed.). Upper Saddle River, NJ: Pearson/Prentice-Hall.

Barker, K., Baker, M., \& Watkins, A. (2021). In City After City, Police Mishandled Black Lives Matter Protests. Retrieved from https://www.nytimes.com/2021/03/20/us/protests-policing-george-floyd.html

Barna, M. (2020). Ending Police Violence Requires Public Health-Based Approach: APHA Statement Guiding Work, 
Outreach. The Nation's Health, 50(6), 1-14.

Blumer, H. (1969). Symbolic interactionism: Perspective and method. Englewood Cliffs, NJ: Prentice-Hall.

Bodapati, M., Anderson, J. F., \& Brinson, T. E. (2008). Revisiting Hubert Blalock's Power Threat Theory to Determine its Effect on Court Workgroup Behavior as it Concerns Structured Sentencing. Criminal Justice Studies: A Critical Journal of Crime, Law and Society, 21(2), 109-134. https://doi.org/10.1080/14786010802159806

Bryant-Davis, T., Adams, T., Alejandre, A., \& Gray, A. A. (2017). The Trauma Lens of Police Violence Against Racial and Ethnic Minorities. Journal of Social Issues, 73(4), 852-871. https://doi.org/10.1111/josi.12251

Chandler, A. (2021). Panel to Discuss Public Health Approaches to Curbing Police Violence. Retrieved from https://sph.washington.edu/news-events/news/police-brutality-during-seattle-2020-protests

Cooper, H. L. F., \& Fullilove, M. (2016). Excessive Police Force as a Public Health Issue. Journal of Urban Health: Bulletin of the New York Academy of Medicine, 93(1), S1-S7. https://doi.org/10.1007/s11524-016-0040-2

Copper, H., Moore, L., Gruskin, S., \& Krieger, N. (2005). Characterizing Perceived Police Violence: Implications for Public Health. American Journal of Public Health, 94(7), 1109-1118. https://doi.org/10.2105/AJPH.94.7.1109

Crenshaw, K., Gotanda, N., Peller, G., \& Thomas, K. (1995). Critical race theory: The key writings that formed the movement. New York, NY: The New Press.

Dahlberg, L., \& Mercy, J. (2009). History of Violence as a Public Health Issue. AMA J Ethics, 11(2), 167-172. https://doi.org/10.1001/virtualmentor.2009.11.2.mhst1-0902

del Carman, R. V. (1991). Civil liabilities in american policing: A text for law enforcement personnel. Englewood Cliffs, New Jersey: Brady Press.

del Carmen, R.V., \& Walker, J.T. (2004). Briefs of leading cases in law enforcement (5th ed.). Cincinnati, OH: Anderson Publishing.

Department of Justice. (2007). Police Stop White, Black, and Hispanic Drivers at Similar Rates. Office of Justice Programs. Retrieved from www.ojp.usdoj.gov/newsroom/pressrelease

Devine, P. G. (1989). Stereotypes and Prejudices: Their Automatic and Controlled Components. Journal of Personality and Social Psychology, 56(1), 5-18. https://doi.org/10.1037/0022-3514.56.1.5

Devine, P. G., Forscher, P. S., Austin, A. J., \& Cox, W. T. L. (2012). Long-Term Reduction in Implicit Bias: A Prejudice Habit-Breaking Intervention. Journal of Experimental Social Psychology, 48(6), 1267-1278. https://doi.org/10.1016/j.jesp.2012.06.003

Eberhardt, J. L., Goff, P. A., Purdie, V. J., \& Davies, P. G. (2004). Seeing Black: Race, Crime, and Visual Processing. Journal of Experimental Social Psychology, 87(6), 876-893. https://doi.org/10.1037/0022-3514.87.6.876

Edwards, F., Lee, H., \& Esposito, M. (2019). Risk of Being Killed by Police Use-of-Force in the U.S. by Age, Race/Ethnicity, and Sex. Proc Natl Acad Sci, 116(34), 16793-16798. https://doi.org/10.1073/pnas.1821204116

Fedina, L., Backes, B. L., Hyun, J. J., Shah, R., Boyoung, N., Link, B. G., \& DeVylder, J. E. (2018). Police Violence Among Women in Four U.S. Cities. Preventive Medicine, 106, 150-156. https://doi.org/10.1016/j.ypmed.2017.10.037

Fix, R. L., Risco, C. M., Fix, S. P., \& Bernat, E. M. (2021). How Racial Identity and Worry About Discrimination Impact Coping Responses to Racial Discrimination Among Black American Community Members. Journal of Racial and Ethnic Health Disparities. https://doi.org/10.1007/s40615-021-00996-8

Fox, J., Blanco, A., Jenkins, J., Tate, J., \& Lowery, W. (2019). What We Have Learned About Police Shootings Five Years After Ferguson. Retrieved from https://www.washingtonpost.com/nation/2019/08/09/what-weve-learned-about-police-shootings-years-after-fergus on/

Gaines, L. K. (2006). An Analysis of Traffic Stop Data in Riverside, California. Police Quarterly, 9(2), $210-233$. https://doi.org/10.1177/1098611105278325

Gaines, L. K., \& Kappeler, V. E. (2008). Policing in America (6th ed.). Newark, NJ: Anderson Publishing.

Gee, G.C., \& Ford, C. L. (2011). Structural Racism and Health Inequities: Old Issues, New Directions. Du Bois Rev, 8(1), 115-132. https://doi.org/10.1017/S1742058X11000130

Glaser, J. (2015). Suspect race: Causes and consequences of racial profiling. New York, NY: Oxford University Press. https://doi.org/10.1093/acprof:oso/9780195370409.001.0001 
Glaser, J., \& Knowles, E. D. (2008). Implicit Motivation to Control Prejudice. Journal of Experimental Social Psychology, 44(1), 164-172. https://doi.org/10.1016/j.jesp.2007.01.002

Goff, P. A., Eberhardt, J. L., Williams, M. J., \& Jackson, M. C. (2008). Not Yet Human: Implicit Knowledge, Historical Dehumanization, and Contemporary Consequences. Journal of Personality and Social Psychology, 94(2), 292-306. https://doi.org/10.1037/0022-3514.94.2.292

Greenwald, A. G., Banaji, M. R., \& Nosek, B. A. (2015). Statistically Small Effects on the Implicit Association Test Can Have Societally Large Effects. Journal of Personality and Social Psychology, 108(4), 553-561. https://doi.org/10.1037/pspa0000016

Kahn, K. B., Goff, P. A., Lee, J. K., \& Motamed, D. (2016). Protecting Whiteness: White Phenotypic Racial Stereo-Typicality Reduces Police Use of Force. Soc Psychol Personal Sci, 7(5), 403-411. https://doi.org/10.1177/1948550616633505

Krieger, N., Chen, J., Waterman, P., Kiang, M., \& Feldman, J. (2015). Police Killings and Police Deaths and Public Health Data and can be Counted. PLoS Med, 12(12), e1001915. https://doi.org/10.1371/journal.pmed.1001915

Krug, E. G., Dahlberg, L. L., Mercy, J. A., Zwi, A. B., \& Lozano, R. (2002). World report on violence and health. Geneva, Switzerland: World Health Organization. https://doi.org/10.1016/S0140-6736(02)11133-0

Lynch, M. J., \& Groves, W. B. (1989). A primer in radical criminology (2nd ed.). New York, NY: Harrow and Heston.

Murphy, M.E. (2020). Black Women are the Victims of Police, Too. The Washington Post. Retrieved from https://www.washingtonpost.com

Park, S. H., \& Glaser, J. (2011). Implicit Motivation to Control Prejudice and Exposure to Counter-Stereotypic Instances Reduce Spontaneous Discriminatory Behavior. Korean Journal of Social and Personality Psychology, 25(4), 107-120. https://doi.org/10.21193/kjspp.2011.25.4.007

Pettigrew, T. F., \& Tropp, L. R. (2006). A Meta-Analytic Test of Intergroup Contact Theory. Journal of Personality and Social Psychology, 90(5), 751-783. https://doi.org/10.1037/0022-3514.90.5.751

Siegel, L. J. (2006). Criminology (9th ed.). Belmont, CA: Thomson/Wadsworth.

Signorelli, W. P. (2006). The crisis of police liability lawsuits. Durham, NC: Carolina Academic Press.

Simmons, R. (2017). The Role of the Prosecutor and the Grand Jury in Police Use of Deadly Force Cases: Restoring the Grand Jury to its Original Purpose, Clev. St. L. Rev., 62(4), 519-534.

Skolnick, J., \& Caplovitz, A. (2001). Guns, Drugs, and Profiling: Ways to Target Guns and Minimize Racial Profiling. Arizona Law Review, 8, 135-152.

Spencer, K. B., Charbonneau., A. K., \& Glaser, J. (2016). Implicit Bias and Policing. Social and Personality Psychology Compass, 10(1), 50-63. https://doi.org/10.1111/spc3.12210

Taylor, E. (1998). A Primer on Critical Race Theory: Who Are the Critical Race Theorists and What are They Saying? The Journal of Blacks in Higher Education, 19, 122-124. https://doi.org/10.2307/2998940

Teplin, L. A. (2000). Keeping the Peace: Police Discretion and Mentally Ill Persons. National Institute of Justice Journal, 8-15. Washington, D.C.: U.S. Department of Justice, Office of Justice Programs. https://doi.org/10.1037/e528652006-002

Thomas, T., Gabbatt, A., \& Barr, C. (2020). Nearly 1,000 Instances of Police Brutality Recorded in US Anti-racism Protests. Retrieved from https://www.theguardian.com/us-news/2020/oct/29/us-police-brutality-protests

Wilkerson, I. (2020). Caste: The origins of our discontent. New York, NY: Random House.

\section{Cases Cited}

City of Canton v. Harris, 489 U.S. 378 (1989)

Monell v. Department of Social Services, 436 U.S. 658 (1978)

Monroe v. Pape, 365 U.S. 167 (1961)

\section{Copyrights}

Copyright for this article is retained by the author(s), with first publication rights granted to the journal.

This is an open-access article distributed under the terms and conditions of the Creative Commons Attribution license which permits unrestricted use, distribution, and reproduction in any medium, provided the original work is properly cited. 